\title{
USING CONCEPT MAPPING TECHNIQUE TO IMPROVE STUDENTS' READING COMPREHENSION AT THE FIRST GRADE OF SMA NEGERI 7 AMBON
}

\author{
Stella Rose Que \\ English Department, Pattimura University, Ambon - Maluku Indonesia \\ que.stella@yahoo.com
}

\begin{abstract}
Reading is complex interaction between the reader and text. Actually reading is not a simple one, because in this skill, students do not only read a text but also try to understand the message or information about the text they learn. In reading process students must know what they get from a passage. This study was conducted to determine students' improvement in reading comprehension by using concept mapping Technique. The result shows that this technique can be successfully used to improve students reading comprehension of SMA Negeri 7 Ambon especially class X. Although there were some problems which raised during teaching learning process but collaboration between English teacher and the writer help this study going smoothly. Through the technique the students can actively participate in the teaching and learning process. This is proved by the result of second cycle, where students who grade bellow 65 improved better after the implementation of concept mapping technique. Besides, the students also show positive responses toward Concept Mapping technique in the teaching learning process so the result in the class is more lively and enjoyable.
\end{abstract}

Keywords: Concept Mapping Technique, Reading Comprehension

\section{Introduction}

Learning to read is an important educational goal. There are important requirements which needs to be considered for both reading understanding and reading success. If someone is able to read, he or she must be able to understand the meaning of the text. According to Grellet (1981) reading involves a variety of skills such as, 1) Understanding conceptual meaning 2) Understanding explicitly stated information 3) Identifying the main point or important information in a piece of discourse. Elisabeth S. Pang (2003) said that Reading is about understanding written text and it has the same idea with Trankersley (2003) who argued that reading is a complex process made up of several interlocking skills and process. It is complex process activity that involves both perception and thought. Depend on the description reading above, reading also can be classified into two types of activities, intensive and extensive reading. a) Intensive reading. Means that reading shorter texts to extract specific information. This activity is likely more to emphasize the accuracy activity involving reading for detail. The process of scanning takes a more prominent role here than skimming. Reader is trying to absorb all the necessary information given, for example: reading dosage instruction for medicine. b) Extensive reading. From this case, reader deals with a longer text 
as a whole, which requires the ability to understand the component part and their contribution to the overall meaning, usually for one's own pleasure. This is a fluency activity, mainly involving global understanding, for example: reading a newspaper, article, short story or novel.

When someone reads a text actually she/he has acquire a language to communicate and share the information of it, therefore it can be said that the process of reading is complexity because it is the interaction between the reader and text. For students in schools, reading is not a simple one, because in this skill, students do not only read a text but also try to understand the message or information about the text they learn.

The result of preliminary study that was done by the researchers on class $\mathrm{X}$ at SMA Negeri 7 Ambon through observation in the class during one month, the researchers found that the main problem was the students did not understand the content of text. Thus, it was difficult for them to answer the questions and participate actively in learning process. This problem had happened because of some factors: First, the teacher distributed the text and asked the students to read it without any discussion about the content of the text first then; they answer the questions that take lot of time and often did many mistakes in it. But at the end the teacher would have answered all the questions. Second, inappropriate choice of text contains too many difficult words. Based on interview with the students in the class after learning process, they said that when they receive the text they could read, but some of them could not catch the idea in the reading text. It is because of there are many difficult words, so it is crucial for them to comprehend content of the text. Tannenbaum R. K. argued (2006) that difficulty of the words in a text makes the students hard to understand the text. Third, the teachers seldom use teaching aid for stimulating student's prior knowledge before reading text. According to Tankersley (2003), the students need to learn by using photos, diagram, charts, picture, and maps to help extend and clarify thinking as they read (2003 p.94). In the other word, teaching aid is the important way in teaching reading and significant also for creative between teacher and students in learning process.

From the explanation above the researchers found many problems in reading process and these made difficult for the students to comprehend the text. Cooke and Laberge (1983) mentioned that if students lack the background knowledge to fully understand the text, the teacher may use a variety of instructional technique such as, building the necessary background knowledge, introducing key concept and clarifying. It also asserted by Harvey and Goudvis (2000) "we must teach our students to access content when they read as well as teach them the strategies they need to better understand text and become more thoughtful readers". So, the teachers need strategy and technique to help the students in reading process. That is why the teaching and learning process should be attractive and enjoyable, even the students could participate actively in the classroom especially to answer the question.

The problems faced by the students above can be solved by using a new technique namely concept mapping that is a technique to build the students analyzed information of the text which is created by David Novak (1970). Concept 
mapping are known under different names like story map, semantic map and narrative map. The typically components of concept map are: Topic, sub topic, definition, Function, and example. This type map also had positive effect on reading comprehension and summarization skill. Meanwhile Plotnik (1997) shows five purpose of concept mapping, (1) to generate ideas (brainstorming), (2) to design complex structure, (3) to communicate complex idea, (4) to new idea explicitly integrating new and old knowledge, (5) to asses understanding or diagnose understanding.

\section{Review of Literature}

Comprehension is the essence of reading, it becomes a primary challenge in teaching or learning of teaching skill, in order to learn or understand the massage of the reading passage, the students are hoped to have the ability to comprehend the written texts. Reading comprehension if further defined as "intentional thinking during which meaning is constructed through interaction between text and the reader". Meanwhile, in the similar statement with Rumellhart Reading comprehension involves the reader, the text, and interaction between reader and the text (1997 p.2) so; reading comprehension is such a kind dialog between the writer and the reader where the information in the text or must be understood by the reader. When an effective reader reads for comprehension and understanding, it is actively engaged and thoughtful process. One of the things that good readers do during the reading process is to make connections between background and the new information in the text. Reading Comprehension also is the construction of the meaning of written text through reciprocal interchange of ideas between the reader and the massage in particular text (National Reading Panel, 2000).In the other word, the reader is not only active for looking at sentences, words in the text but the importance for the reader they must understand the meaning and their ability for concluding the information from text.

Comprehension is the heart and goal of reading, since the purpose of all reading is to gather meaning from the printed page. Many students often have difficulty comprehending what they have read. Tankersley $(2003:$ p.137) said that students who have difficulty reading often do not understand how to go about the process. Klinger (2007: p.5) stated that rather, many children who are able to read effortlessly actually are unable to comprehend the information. Some students are likely to demonstrate difficulties with decoding, fluency, and vocabulary. The difficulty in any of these areas will interfere with reading comprehension. It seems that one reason of this interference is that readers only have so much short term cognitive or thinking capacity for a task if too much to decoding, little capacity is available for focusing on comprehension.

For many students who learn English as foreign language, reading comprehension is a major problem. Khand (2000) stated that there are mainly three causes for poor reading comprehension: 1) The person has a language problem: Language plays a vital role in reading. Its role in reading can be compared to the role of running in the game of soccer or ice-skating in the game of ice hockey. One cannot play soccer one cannot run, and one cannot play ice hockey if one cannot skate. one cannot read a book in language unless one knows that particular 
language. If a child's knowledge of English is poor, then his readings will also are poor, and naturally also his reading comprehension. 2) The foundational skills of reading have not been automated: when a person attempts to speak a language in which he has not become automatic yet, he will necessarily have to divide his attention between the content of the massage and language itself. 3). The reader is unable to decode the written words: The decoding of the written word is very important aspect of reading act. Without being able to decode the written word, reading comprehension is impossible. This explains why some children can read without understanding what they are reading. 4). A decoding skill that is closely related to that of integration is calcification. When a person see a chair, although he may never have seen a chair exactly like this one, he will nevertheless immediately recognize it is a chair, because he is familiar with the class of objects we call chair .This implies that, whenever a name is described to object.

To improve student's reading comprehension the teachers need effective way to motivate the students how to be good reader. Elisabeth S. Pang et all describes their ways to improve reading comprehension like, using co-operative or group learning, Graphic organizer, asking and answering question, story structure, summarizing, and focusing on vocabulary. (2003 p.14). Based on steps above it can help the students in reading process because there is opportunity for interacting actively between the students and the teacher to comprehend the text. Besides, Klinger (2007 p.4) claimed that teacher can improve the poor students reading comprehension, if teacher: 1) Teach strategies that have been documented as effective in promoting reading comprehension. 2) Design instruction that incorporates effective principles if direct instruction and strategy instruction. 3) Monitoring students' progress and make adjustment accordingly

Tankersley (2003: p.6) also stated, "we must teach our students to access content when they read as well as teach the strategies or technique they need better understand text and become more thoughtful readers". Moreover, selection of material for teaching reading also takes a great part in resulting learners' better comprehension. Carl and Roger (2000) gave advices to select stories or books with (1) less number of difficult word (2) Direct, on-convoluted syntax; (3) Short passage that delivers clear messages (4) Subheads that organize the flow of ideas and (5) Helpful illustration .If the teachers can fulfill all of these advices, the learners can get full assistance in result comprehension.

Concept mapping are known under different names like story map, semantic map and narrative map. The typically components of concept map are: Topic, sub topic, definition, Function, and example. This type map also had positive effect on reading comprehension and summarization skill. Meanwhile Daley (2010) shows five purpose of concept mapping, (1) to generate ideas (brainstorming), (2) to design complex structure, (3) to communicate complex idea, (4) to new idea explicitly integrating new and old knowledge, (5) to asses understanding or diagnose understanding.

According to Stoica at.all (2016), there are some procedures in applying Concept Mapping Technique, they are; 1) Select a text that related your curriculum, 2) Gives some questions that have relation with the topic (brainstorming), 3) Drew on the board is called a concept map. 4) Explain that concept map will organize the 
important ideas in text. 5) Explained structure of concept map which consist of : a) Main topic, b) Sub topic and, c) Several boxes connect with arrows it explained definition, example from sub topic. 4) Then, distribute the text, and 5) after reading, complete the concept map which information in the text.

Mayer (1989) said that concept maps help learners (a) to creatively transfer information to solve problems (b) to organize information coherently in reading passage, (c) provides a convenient and concise schematic summary of learning. Stice \& Alvarez (1978) also stated that concept mapping gives students a sense of confidence in manipulating and rearranging information, increases concentration, focus on the task, and improves motivation for self-directed learning. The explanation above implies that concept mapping appears to be an effective way to teach and learn about new information and overarching concepts. Besides, concept mapping indirect can helps the students to organize the importance ideas in the reading passage. Besides the benefit of using concept mapping in improving student's reading performance, Pelley $(1980$, p.17) suggests several things as a precaution in the implementation of concept mapping technique;

1. It may take sometimes to learn the process. It means that in the teaching learning process of concept mapping technique the students spent much time especially in their effort to comprehend the parts of this technique, such as topic, sub topic, definition, function and example.

2. It may take sometimes to do the process. The risk of facing boredom in students' part may occur. To do the process of concept mapping technique may run the risk of spending times, if not planned carefully in the teachers' part. Therefore, the students should better be prepared as necessary before applying this technique.

3. It is a technique that hierarchically structured and would intertwined one to another. If one of the parts is missing the students may get confused to arrange the information into a correct form. So teachers in this case, have to make sure that the structure involved in this technique is a complete structure.

There are two research findings of concept mapping technique. They are: Improving Reading Comprehension through concept mapping technique for eleventh grade students of IPS 3 of Tambakberas Jombang by Effi Fadhila (2008/2009) and using concept mapping to improve students in science class by Braselton \& Decker (1994).

Fadhila (2008/2009) explained this technique can improve the reading comprehension of the eleventh grade student. The fact of problems which emerged from teaching reading comprehension was low ability to comprehend the text until they could not answer the question. Their achievement was still under minimum standard of learning success. This study is classroom action research with a collaborative design. This subject of the study was the students of the eleventh grade of IPS 3 of MAN Tambakberas Jombang comparising OF 45 students in the 2008/2009 academic year. This study was conducted in there cycle, each of which consist of two meetings. The findings of this study also shows that use of appropriate model concept mapping technique can improve the students reading comprehension. 
Concept mapping also can improve students in science class, Braselton \& Decker (1994), The study was conducted with 23 fifth- grade students in Ata Elementary school, Tarbson Turkey the students who participated $51 \%$ were male and 49 were female. There are three instruments were used in this study 1)multiple choice test 2) concept mapping scoring rubric 3)students interview Question. The result indicated that using this technique got benefited from treatment, they also active to participate in learning process.

Compared with those two different studies the writer chooses classroom action research of this study. This study was conducted in SMA Negeri 7 Ambon it carried out in first semester 2018/2019 with total students are 22. The main problems which emerged from teaching reading comprehension were the students did not understand content of the text and as a result they were become passive in class especially in question answer session. There are two instruments were used (1) Essay test and (2) questionnaire. This study was conducted in two in cycles, each of which consist of three meetings and over all the students showed good improvement in every cycle, they can know deeply information in the text before they enter question answer session. They also active in learning process

\section{Research Method}

An action research method is used in this study with two cycles conducting the research with the subjects are the students at grade X of SMA Negeri 7 Ambon. It carried out in the first semester of 2018/2019.The numbers of students are 22. This research method has some steps that must be involved in each cycle. The steps are planning, acting, observing and reflecting.

In the planning step, the researchers collaborate with English teacher for make planning such as, preparing the lesson plan, teaching material, and research schedule. In acting step, the role of the researcher as a teacher that treat the students by using concept mapping technique. Each cycle contains six meetings. For the evaluating step, this stage dealing with data collection of this study that took after the implementation of the technique. After that, the writer decided whether students result achieve the indicators of success or not, and whether the implementation of concept mapping technique runs well through the observation sheets. The last step is reflection, the researchers and English teacher discussed the things that have been done in the action implementation. This can be a reflection tool for the writer to see how concept mapping technique can improve their reading comprehension and as handout to continue for the next cycle.

The data of the study took from the result of test, the result of questioner and observation sheet distributed to the students when the writer implemented the concept mapping technique. The instruments for collecting: 1) Test; to measure students' improvement after the application of the technique, the writer conducted a test. 2) Observation sheet is used to observe the implementation of concept mapping technique in improving reading comprehension. 3.) Questionnaire is a written list of questions to be answered by students

The datum of this research is analyzed in quantitatively and qualitatively ways. The quantitatively way belongs to the test and questionnaire while qualitatively way belongs to observation checklist. 


\section{Research Findings}

The result of the datum can be discussed into three types of datum; test, observation checklist and questionnaire in cycle 1 and cycle 2 . The datum shows the progress of students' reading comprehension after they have teaching by the concept mapping technique. This action research was done in two cycles during one month and each cycle consisted of three meetings. The findings showed that both of criteria of success were successfully achieved in the second cycle. So the researchers stopped and reported. The following is the discussion on the accomplishment of criteria of success.

\section{The result of the test}

Figure 1. The result of pre and post test in the first cycle

\subsubsection{Percentage of Students' Score for Pre Test}

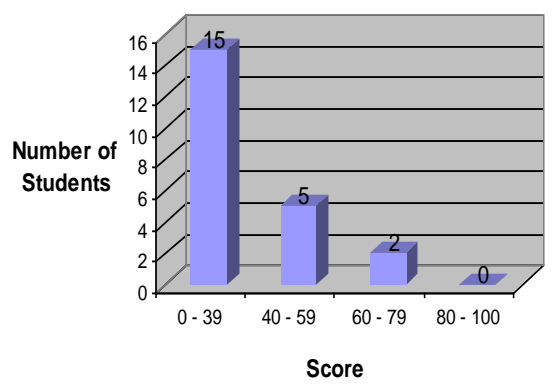

4.1.2. Percentage of Students Score for First Cycle

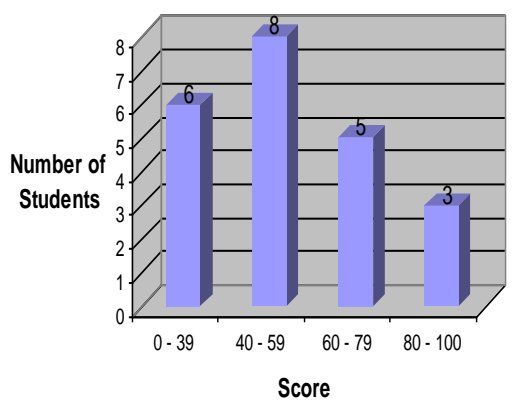

The figures above show for pre test there were 15 of students $(68,2 \%)$ got lowest score that is $0-39 ; 5$ of students $(22,7 \%)$ got score $40-59$ while 2 of students $(9,1 \%)$ got score $60-79$ and there were no students got score $80-100$ in pre test. It means that most of the students had problem to answer the question based on the text before the writer applied concept mapping technique. Meanwhile for post test From the graphic shows that the students' score of the first cycle, which has different score with their result of pre test. Result of first cycle indicated that there 
were 6 students $(27,3 \%)$ got score $0-39$; and 8 students $(36,4 \%)$ got score $40-59$; while in the next level there were 5 of students $(36,4 \%)$ got score $60-79$ and 3 students $(13,6 \%)$ got score $80-100$.

These graphics show that after applying concept mapping technique in the first cycle showed that there were $27,3 \%$ or 6 students got "Fair" score and there were $36,4 \%$ or 8 students got "Enough". It means that the criteria of success were not achieved yet by the students. It happened because of some factors. First from teaching material, the writer found the text that given for student it was not interesting. So, it will become difficult for the students to be active in the class. Second related with the way the writer explained the technique, the students still confused to determine structure of concept mapping, likes Topic, Sub topic, Definition, Function, and Example in the text, due to unclear instruction and explanation by the teacher about the technique itself, so that it influenced to their activity. Third, it is connected with classroom management, when the writer inferred that filling concept mapping sheet individually still ineffective for the students because it was difficult to control them one by one. Besides that, the students also wasting much time work individually.

Based on explanation above, the researchers and classroom teacher made some planning before they moved in the second cycle. The planning was made to overcome the problems in the first cycle. First problem it was about teaching material specifically with the text. The writer and the teacher tried to give interesting and simple text for the students; it was about "Taman Sari". Second, related with concept mapping technique, the writer explained structure of concept mapping technique clearly and also gave example in the text. The last it was about classroom management, in applying this technique the writer and the teacher decided to manage students in the group one group consists of 4-5 and there were competence students sit in the group. So, it helped them to actively and cooperatively share their ideas.

\subsubsection{Percentage of Students' Score of Second Cycle}

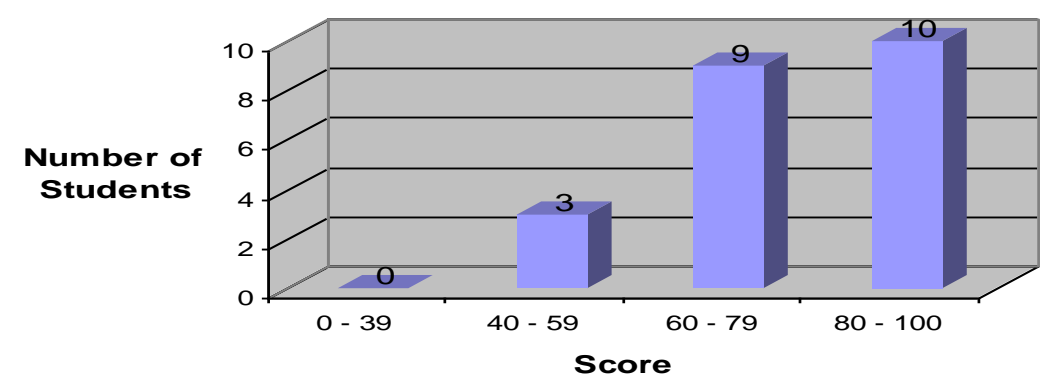

Teaching material is an important component in supporting learning activities specifically in selecting a text; teacher should use interesting text to gain students attention, as Kral (2003) states that the first step teacher should do is selecting the most appropriate materials, based on his knowledge of students' needs and their cognitive level. Based on experience in the first cycle the writer gave 
descriptive text which the title "Plant", the writer found that this text was not interest for the students. Therefore, in the second cycle collaboratively the writer and the teacher selected simple text which interest. This text could motivate the students in filling concept mapping sheet, they became active during teaching learning process.

Another factor was about understanding of the concept mapping technique. In the first cycle the students look confused in determining structure of concept mapping technique like Topic, sub topic, definition, function and example. It happened because of unclear instruction and explanation from the writer and to enter in the second cycle the writer explained clearly structure of concept mapping technique.

The last factors about classroom management, when the writer asked the students filling concept mapping sheet individually still ineffective for the students because it was difficult to control them one by one. Besides that, the students also wasting much time work individually.

\section{The result of Questionnaire}

The result of questionnaire showed that the majority of the students gave good response when learnt use concept mapping technique. It was given at the last meeting to 22 students in the class. After the questionnaires were filled the writer organized and tabulated data and the result can be seen in the graphic:

\section{Graphic 4.1.4. Data Students' Result of Questionnaire}

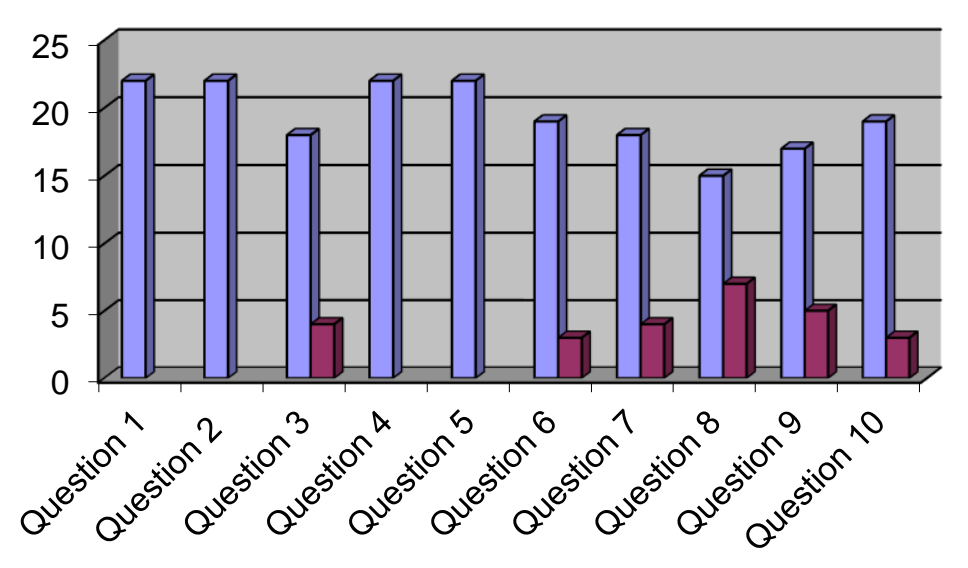

From the data on the graphic 4.2.1. Above, it can show that: 1)There were 22 students or $100 \%$ agreed that reading is important, 2) All of students agreed that to understand content of the text was very important. 3) There were 20 students or $(91 \%)$ answered that understand text was hard for them and 2 students or $(9 \%)$ they can understand text well. 4). There were 22 students or (100\%) agreed that concept mapping technique help them to understand content of the text.5) All 
students agreed that when use concept mapping technique it was pleasure for them. 6) There were 17 students or (79\%) active in the learning process when use this technique and 5 students or (13) felt bored can't active in the learning process. 7) There were 22 students or $(100 \%)$ can able to comprehend the question based on the text. 8) There were 15 students or $(68 \%)$ felt easy to follow procedure of concept mapping technique and 7 students or $(23 \%)$ felt not easy to follow procedure of concept mapping. 9)There were 17 students or (87\%) felt easy identified information of the text when used this technique and 5 students or $(13 \%)$ still confused to identify the information of the text, and 10) There were 19 students or $(89 \%)$ stated that easy to summarize the text using this technique and there were 3 students or (12\%) stated no easy to summarize the text.

\section{The Result of Observation Sheet}

In this study, the researchers collected data by some instruments. One of them is observation sheet. Observation sheet is used to find student's involvement or reaction in the teaching learning process. The observation sheets consist of three parts. They are how the writer opening the lesson. It has relation with brainstorming. Second, it was about the material and participant of students during teaching and learning process. Third about how far the students can understand the text using concept mapping technique. From the result of observation sheet, it can be concluded that students gave their positive response at the implementation of concept mapping technique

\section{Discussion}

\section{The usefulness of using Concept mapping technique in improving students' reading Comprehension}

Talking about students reading comprehension in reading class before and after applying this technique, the writer had some data about that. Before applying Concept Mapping Technique the students' reading comprehension was poor. It can be seen when the teacher distributed text for the students and asked them to answer the question. They were not active and always wasting much time to do the task. They also lack of vocabulary because they did not bring the dictionary and it made them did not know some unfamiliar words in reading passage.

For the first applying Concept Mapping technique some of students look confused about how to use this technique in reading passage but the writer tried to give explanation more detail about structure and purpose of concept mapping technique, students really paid attention in using this technique. They were followed step by step. Before doing it the writer distributed text and the students fill concept mapping sheet and continued to answer the questions. After applying this technique the students were participate in teaching learning process. The students admitted that through Concept mapping technique, they had no difficulties to answer the question. Even, they quickly can know and organize content of the text especially for long text.

The effectiveness of Concept Mapping technique to solve the student's problem from first cycle until second cycle had achieved indicator of success well. 
It can be seen in the result of student's progress after implementation of the technique. The writer made test at the first meeting and the end of each cycle from result of the test, the score showed that students whose grades bellow 65 were improving better. It means that Concept Mapping technique is effective way where the students can know detail information of the text. In addition, according to Downing \& Morris (1984), Concept Mapping helps the students to manage reading difficulty more effectively by providing a logical process of thinking through reflecting on reasoning and judging the content of a readings

The effectiveness of Concept Mapping technique in teaching reading also was shown before the students answered the question of the text they can use structure of this technique like Topic, sub topic, definition, function and example it used to organize information of the text until text will be easy to understand

\section{The Student's Responses of Concept Mapping Technique}

The students' responses showed positive attitude toward the Concept Mapping technique in the learning process. To find the positive responses, the writer used two instrument data; they were observation sheet and questionnaire.

Observation sheet used to know student's involvement or interaction in the reading process and class activities. The first positive responses were shown when the writer opened the lesson and explained Concept Mapping Technique, some students asked the writer; How was the technique worked, What is the useful of this technique in reading process? What is different between Topic and Sub topic? These questions showed that the students really participated when they use this technique in reading class and at the while activity, students pay attention in using Concept Mapping technique especially when the writer manage the students in the group, they were be active and cooperative to share their ideas to fill Concept Mapping sheet and as result in the last activity the students can do the task correctly.

The other instrument was questionnaire. Questionnaire is used to know student's opinion about Concept Mapping Technique application. It contained of 10 questions and from of over all information that the writer got from student's, all of them argued we can increase our knowledge " Reading is the key of successfulness". Besides, They think that to understand content of the text is very important for their comprehending. Then, most of them said to catch the meaning of the text is very difficult, so they need dictionary to help them in finding unfamiliar words in the text because lack of vocabulary of the students.

Related to this technique all students argued that through Concept mapping technique was easy and help full for them to overcome problems in comprehending text. This technique had description about text that they will read, before the students answer the question. It means that, the structure of concept mapping technique help them to know content of the text. Besides, the procedure of this technique was very easy followed by the students.

\section{Conclusion}

From all result of this study the writer can concluded that Concept mapping as technique to improve students reading comprehension of SMA Negeri 7 Ambon, especially class $x$ is successful. Although there were some problems which raised 
during teaching learning process but collaboration between English teacher and the writer help this study going smoothly. Through the technique the students can organize and identify information deeply in the text before they come to reading activity. Besides, this technique has good influenced in group discussion where the students can share their ideas and work actively to fill concept mapping sheet. The students also show positive responses toward Concept Mapping technique in the teaching learning process so the result in the class is more lively and enjoyable.

Based on conclusion, the suggestion is addressed to English teacher in the SMA Negeri 7 Ambon for the teacher it is needed to develop and implemented Concept Mapping technique in the class especially in reading class. It is proven that this technique is effectively can improve students reading comprehension. The students can know deeply content of the text and participate in reading process.

Finally, the writer realizes that this research still not perfect yet so the writer expects for the next, this technique can be used better to improve students reading comprehension.

\section{References}

Asan,A. (2007).Concept Mapping in Science Class: A Case Study of fifth grade students.Educational Technology \& Society .Retrieved on June 18, 2010

Constanta,T.I.(2006).Jurnal Tahury,Vol 3,No1,Hal.31.FKIP Universitas Pattimura

Daley, B. (2010). Concept maps: Practice applications in adult education and human resource development [Perspectives on Practice]. New Horizons in Adult Education and Human Resource Development, 24(2-4), 30-36. http://education.fiu.edu/newhorizons

Dolehanty, C. (2008). Concept Mapping and Reading Comprehension. http://els.earlham.edu//gpe/files/30/150/CherieD2008.pdf. Retrieved on June 10, 2010

Duke. Nell. K \& Pearson. P. D (2002). Effective Practices for Developing Reading Comprehension. Retrieved on June 10, 2010 Available at: red_c7_16r_pa_duke_Pdf

Eric. D (2007). Concept mapping: a graphical system for understanding the relationship between concepts. http://www.ericdegests.org/19981/concept.htm. Download in July 102008

Fadillah, E. (2008). Improving Reading Comprehension of the eleventh grade students Tambak beras Jombang. Retrieved on July 20, 2010, from http://Karya Ilmiah.um.ac.Id/INDEX.php/disertasi/article/view/4486 Just read now. (n.d). Retrieved on June 10, 2010 from http://www.justreadnow.com/strategies/analysis/htm

Khand, Zianudin. (2004). Teaching Reading Skill; Problem and Suggestion. http://www.teachingreadingskills.edu. Retrieved on July 8, 2010.

Klinger,J. K. Vaugh, S. \& Boardman, A. (2007). Teaching Reading Comprehension to students With Learning Difficulties. New York : The Guilford Press. 
National Reading Panel.2000.Teaching children to read: an evidence Based assessment of the scientific research literature on reading and its implications for reading instruction. Rockville,MD ;

National Institute of ChIld Health and Human Development Available at: http://www.nichd.nih.gov/publication/nrp/report.htm

Pang, E. S., Bernhardt, B. E, \& Kamil , M. (n.d). Teaching Reading. Retrieved on July 15, 2010 from International Academy of Education

Sujana, N. (1989). Penelitian proses belajar mengajar. Bandung : PT Remaja Rosdakarya

Stoica At.all (2016). Concept Maps, a must for the modern teaching-learning process.

Tankersley, K. (2003).The Threads of Reading, Strategies for Literacy Development Association for Supervision and Curriculum Development, Virginia, USA.

Tannenbaum, R .K., Torgesen, K. J.,\& Wagner, k. R.(2006).Relationship between Word Knowledge and Reading Comprehension. Florida state university: Lawrence Erlbaum Associated, Inc.

Teaching concept mapping. Retrieved on June 11, 2010 from www.deltaeducation.com/downloads/sampleseeds/122804

Wikipedia. "Concept mapping and reading comprehension". Retrieved on July 10, 2010 https://en.wikipedia.org/wiki/concept map.downloads

Wikipedia. (2008) Reading (process).Retrieved on July 10, 2010, from http://en.wikipedia.org/wiki/Reading\% 28 process $\% 29$ 